Research

Open Access

\title{
Mechanical ventilation using non-injurious ventilation settings causes lung injury in the absence of pre-existing lung injury in healthy mice
}

\author{
Esther K Wolthuis ${ }^{1,2,3}$, Alexander PJ Vlaar ${ }^{1,3}$, Goda Choi ${ }^{3,4}$, Joris JTH Roelofs ${ }^{5}$, \\ Nicole P Juffermans ${ }^{1,3}$ and Marcus J Schultz ${ }^{1,3,6}$
}

\author{
1Department of Intensive Care Medicine, University of Amsterdam, Meibergdreef 9, 1105 AZ Amsterdam, The Netherlands \\ 2Department of Anesthesiology, University of Amsterdam, Meibergdreef 9, 1105 AZ Amsterdam, The Netherlands \\ ${ }^{3}$ Laboratory of Experimental Intensive Care and Anesthesiology (LEICA), University of Amsterdam, Meibergdreef 9, 1105 AZ Amsterdam, The \\ Netherlands \\ ${ }^{4}$ Department of Internal Medicine, University of Amsterdam, Meibergdreef 9, 1105 AZ Amsterdam, The Netherlands \\ 5Department of Pathology, University of Amsterdam, Meibergdreef 9, 1105 AZ Amsterdam, The Netherlands \\ 6HERMES Critical Care Group, Amsterdam, The Netherlands \\ Corresponding author: Esther K Wolthuis, e.k.wolthuis@amc.uva.nl
}

Received: 18 Sep 2008 Revisions requested: 8 Oct 2008 Revisions received: 19 Nov 2008 Accepted: 19 Jan 2009 Published: 19 Jan 2009

Critical Care 2009, 13:R1 (doi:10.1186/cc7688)

This article is online at: http://ccforum.com/content/13/1/R1

(c) 2009 Wolthuis et al.; licensee BioMed Central Ltd.

This is an open access article distributed under the terms of the Creative Commons Attribution License (http://creativecommons.org/licenses/by/2.0), which permits unrestricted use, distribution, and reproduction in any medium, provided the original work is properly cited.

\begin{abstract}
Introduction Mechanical ventilation (MV) may cause ventilatorinduced lung injury (VILI). Present models of VILI use exceptionally large tidal volumes, causing gross lung injury and haemodynamic shock. In addition, animals are ventilated for a relative short period of time and only after a 'priming' pulmonary insult. Finally, it is uncertain whether metabolic acidosis, which frequently develops in models of VILI, should be prevented. To study VILI in healthy mice, the authors used a MV model with clinically relevant ventilator settings, avoiding massive damage of lung structures and shock, and preventing metabolic acidosis.

Methods Healthy C57BI/6 mice $(n=66)$ or BALB/c mice $(n=$ 66) were ventilated (tidal volume $=7.5 \mathrm{ml} / \mathrm{kg}$ or $15 \mathrm{ml} / \mathrm{kg}$; positive end-expiratory pressure $=2 \mathrm{cmH}_{2} \mathrm{O}$; fraction of inspired oxygen $=0.5$ ) for five hours. Normal saline or sodium bicarbonate were used to correct for hypovolaemia. Lung histopathology, lung wet-to-dry ratio, bronchoalveolar lavage fluid protein content, neutrophil influx and levels of proinflammatory cytokines and coagulation factors were measured.
\end{abstract}

Results Animals remained haemodynamically stable throughout the whole experiment. Lung histopathological changes were minor, although significantly more histopathological changes were found after five hours of MV with a larger tidal volume. Lung histopathological changes were no different between the strains. In both strains and with both ventilator settings, MV caused higher wet-to-dry ratios, higher bronchoalveolar lavage fluid protein levels and more influx of neutrophils, and higher levels of proinflammatory cytokines and coagulation factors. Also, with MV higher systemic levels of cytokines were measured. All parameters were higher with larger tidal volumes. Correcting for metabolic acidosis did not alter endpoints.

Conclusions MV induces VILI, in the absence of a priming pulmonary insult and even with use of relevant (least injurious) ventilator settings. This model offers opportunities to study the pathophysiological mechanisms behind VILI and the contribution of MV to lung injury in the absence of pre-existing lung injury.

\section{Introduction}

Mechanical ventilation (MV) may aggravate pre-existing lung injury or even cause lung injury in healthy lungs, a phenomenon frequently referred to as ventilator-induced lung injury (VILI).

BALF: broncho-alveolar lavage fluid; ELISA: enzyme-linked immunosorbent assay; $\mathrm{H} \& \mathrm{E}$ : haematoxylin \& eosin; $\mathrm{HV}_{\mathrm{T}}$ : High tidal volume; IL: interleukin; IQR: interquartile range; $\mathrm{KC}$ : keratinocyte-derived chemokine; $\mathrm{LV}_{\mathrm{T}}$ : low tidal volume; MIP: macrophage inflammatory protein; $\mathrm{MV}$ : mechanical ventilation; $\mathrm{PaCO}_{2}$ : partial pressure of arterial carbon dioxide; PAl: plasminogen activator inhibitor; $\mathrm{PaO}_{2}:$ Partial pressure of arterial oxygen; PBW: predicted bodyweight; PEEP: positive end-expiratory pressure; SD: standard deviation; TATc: thrombin-antithrombin complexes; TNF: tumour necrosis factor; VILI: ventilator-induced lung injury; $\mathrm{V}_{\mathrm{T}}$ : tidal volume. 
Present strategies at minimising VILI in critically ill patients consist of using low tidal volumes $\left(\mathrm{V}_{\mathrm{T}}\right)$ [1]. However, additional strategies to attenuate pulmonary inflammation may be useful to further reduce VILI. Adequate animal models are also required, to test various treatment strategies. However, existing animal models of MV have considerable disadvantages.

Most models of VILI use very high $\mathrm{V}_{\mathrm{T}}$ and/or inspiratory pressures that are considerably higher than those used in the clinical management of patients [2-6]. High $\mathrm{V}_{\mathrm{T}}$ may compromise systemic circulation, eventually leading to shock. Wilson and colleagues used an MV strategy in which mice were ventilated with a $V_{T}$ of $34.5 \mathrm{ml} / \mathrm{kg}$ for a duration of 156 minutes until mean blood pressure fell below $45 \mathrm{mmHg}[5,6]$. Consequently, duration of $\mathrm{MV}$ is relatively short and maybe too short to draw meaningful conclusions. In addition, most models of VILI lungs are 'primed' before starting MV [7-11]. Indeed, animals are challenged before onset of MV, for instance for lipopolysaccharide causing lung injury $[7,11]$. Such an approach prevents conclusions on the deleterious effects of MV in the absence of pre-existing lung injury being drawn. One final problem may be that infusion of saline solution to correct for low arterial blood pressures leads to metabolic acidosis in models of VILI $[12,13]$, although metabolic acidosis may influence several endpoints of VILI $[14,15]$. It is uncertain whether metabolic acidosis should be corrected in models of VILI.

The aim of the present investigation was to set up a model of VILI in healthy animals. We chose an MV strategy that closely reflected the human setting by using clinically relevant $\mathrm{V}_{\mathrm{T}}$, preventing shock and gross lung histopathological changes, and compared lower $\mathrm{V}_{\mathrm{T}}$ with higher $\mathrm{V}_{\mathrm{T}}$ with respect to several endpoints of VILI. In addition, we hypothesised preventing metabolic acidosis to affect endpoints of VILI. Therefore we compared two strategies for fluid resuscitation, using either normal saline or sodium bicarbonate.

\section{Materials and methods}

The study was approved by the Animal Care And Use Committee of the Academic Medical Center. Animal procedures were carried out in compliance with Institutional Standards for Human Care and Use of Laboratory Animals.

\section{Animals}

Experiments were performed with healthy male C57Bl/6 $(\mathrm{n}=$ $66)$ and BALB/c mice $(n=66)$ (Charles River, Someren, the Netherlands), aged 8 to 10 weeks, with weights ranging from 19 to $25 \mathrm{~g}$. Two groups of control animals served either as non-ventilated controls for blood gas analysis at baseline $(n=$ 6 for each strain) or as non-ventilated controls after five hours ( $n=12$ for each strain). The other animals were all mechanically ventilated with two different MV-strategies and two different fluid support strategies. Thus, five groups of animals of each mice strain were compared.

\section{Instrumentation and anesthesia}

Throughout the experiments, rectal temperature was maintained between 36.5 and $37.5^{\circ} \mathrm{C}$ using a warming path. Anaesthesia was achieved with intraperitoneal injection of a mix of $100 \mathrm{mg} / \mathrm{ml}$ ketamine (Eurovet Animal Health B.V., Bladel, the Netherlands), $1 \mathrm{mg} / \mathrm{ml}$ medetomidine (Pfizer Animal Health B.V., Capelle a/d IJssel, the Netherlands) and 0.5 $\mathrm{mg} / \mathrm{ml}$ atropine (Pharmachemie, Haarlem, the Netherlands; $\mathrm{KMA}$ ). Induction of anaesthesia was performed by injecting $7.5 \mu \mathrm{l} / \mathrm{g}$ of induction KMA mix (consisting of $1.26 \mathrm{ml}$ ketamine, $0.2 \mathrm{ml}$ medetomidine and $1 \mathrm{ml}$ atropine). To maintain anaesthesia, $10 \mu \mathrm{l} / \mathrm{g}$ of maintenance KMA mix (consisting of $0.72 \mathrm{ml}$ ketamine, $0.08 \mathrm{ml}$ medetomidine and $0.3 \mathrm{ml}$ atropine) was given, via an intraperitoneally placed catheter every hour.

\section{Mechanical ventilation strategies}

A Y-tube connector, $1.0 \mathrm{~mm}$ outer diameter and $0.6 \mathrm{~mm}$ inner diameter (VBM Medizintechnik GmbH, Sulz am Neckar, Germany) was surgically inserted into the trachea under general anaesthesia. Mice were placed in a supine position and connected to a ventilator (Servo $900 \mathrm{C}$, Siemens, Sweden). Simultaneously, six mice were pressure-controlled ventilated with either an inspiratory pressure of $10 \mathrm{cmH}_{2} \mathrm{O}$ (resulting in $\mathrm{V}_{\mathrm{T}}$ of about $7.5 \mathrm{ml} / \mathrm{kg}$; low $\mathrm{V}_{\mathrm{T}}\left(\mathrm{LV}_{\mathrm{T}}\right)$ ) or an inspiratory pressure of $18 \mathrm{cmH}_{2} \mathrm{O}$ (resulting in $\mathrm{V}_{\mathrm{T}}$ of about $15 \mathrm{ml} / \mathrm{kg}$; high $\mathrm{V}_{\mathrm{T}}\left(\mathrm{HV}_{\mathrm{T}}\right)$ ).

In $\mathrm{C} 57 \mathrm{BI} / 6$ mice, respiratory rate was set at 120 breaths/ minute and 70 breaths/minute with $\mathrm{LV}_{T}$ and $\mathrm{HV}_{\mathrm{T}}$, respectively; in BALB/c mice, respiratory rate was set at 100 breaths/ minute and 70 breaths/minute with $L_{T}$ and $H V_{T}$, respectively. Preliminary studies showed these respiratory settings resulted in normal partial pressure of arterial carbon dioxide $\left(\mathrm{PaCO}_{2}\right)$ values after five hours of MV in the different mice strains. Positive end-expiratory pressure (PEEP) was set at $2 \mathrm{cmH}_{2} \mathrm{O}$ with both MV strategies. The fraction of inspired oxygen was kept at 0.5 throughout the experiment. The inspiration to expiration ratio was kept at $1: 1$ throughout the experiment.

\section{Fluid support strategies}

Mice received an intraperitoneal bolus of $1 \mathrm{ml}$ normal saline one hour before the start of $\mathrm{MV}$, followed by $0.2 \mathrm{ml}$ normal saline (sodium chloride $(\mathrm{NaCl}) 0.9 \%$ ) or $0.2 \mathrm{ml}$ sodium bicarbonate (containing $200 \mathrm{mM}$ sodium and bicarbonate) administered via the intraperitoneal catheter every 30 minutes. Preliminary studies showed this fluid strategy to adequately compensate for insensible and observed fluid loss, and to keep the animals haemodynamically stable.

\section{Haemodynamic and ventilatory monitoring}

Systolic blood pressure and heart rate were non-invasively monitored using a murine tail-cuff system (ADInstruments, Spenbach, Germany). Blood pressure and pulse were measured directly after the start of MV, after 2.5 hours and 5 hours of MV. The data were recorded on a data acquisition system (PowerLab/4SP, ADInstruments, Spenbach, Germany). An 
average systolic blood pressure and heart rate were taken from three consecutive measurements.

$V_{T}$ was checked hourly with a specially designed Fleisch-tube connected to the body-plethysmograph. The flow signal was integrated from a differential pressure transducer and data were recorded and digitised online using a 16-channel data acquisition program (ATCODAS, Dataq Instruments Inc, Akron, $\mathrm{OH}$ ) and stored on a computer for post acquisition offline analysis. A minimum of five consecutive breaths were selected for analysis of the digitised $\mathrm{V}_{\mathrm{T}}$ signals.

\section{Study groups}

Non-ventilated control mice were selected for blood gas analysis at baseline (for both strains $n=6$ ): animals were handled one week before the experiment to decrease stress activation. After induction of anaesthesia with isoflurane arterial blood was taken from the left ventricle by heart puncture within 30 seconds.

$L V_{T}$ mice receiving either normal saline $(n=12)$ or sodium bicarbonate $(n=12)$ and $\mathrm{HV}_{T}$ mice receiving either saline $(\mathrm{n}=$ $12)$ or sodium bicarbonate $(n=12)$ were mechanically ventilated for five hours and then euthanased. Non-ventilated control mice $(n=12)$ received half the dose of induction anaesthesia, were spontaneously breathing and then euthanased after five hours.

\section{Measurements}

The first series of mice $(n=6)$ were euthanased and blood was drawn from the vena cava inferior into a sterile syringe, transferred to EDTA-coated tubes and immediately placed on ice. Blood samples of two mice were pooled together. Bronchoalveolar lavage fluid (BALF) was obtained from the right lung; the left lung was used to measure the wet-to-dry ratio. In a second series of mice $(n=6)$, blood was sampled from the carotid artery for blood gas analysis. The lungs of these mice were used for homogenate (right lung) and histopathology (left lung).

For wet-to-dry ratios the lung was weighed and subsequently dried for three days in an oven at $65^{\circ} \mathrm{C}$. The right lung was removed and snap frozen in liquid nitrogen. These frozen specimens were suspended in four volumes of sterile isotonic saline and subsequently lysed in one volume of lysis buffer (150 mM NaCl, $15 \mathrm{mM}$ Tris (tris(hydroxymethyl)aminomethane), $1 \mathrm{mM} \mathrm{MgCl} . \mathrm{H}_{2} \mathrm{O}, 1 \mathrm{mM} \mathrm{CaCl} 2,1 \%$ Triton X-100, 100 $\mu \mathrm{g} / \mathrm{mL}$ pepstatin A, leupeptin and aprotinin, $\mathrm{pH}$ 7.4) and incubated at $4^{\circ} \mathrm{C}$ for 30 minutes. Homogenates were spun at $3400 \mathrm{rpm}$ at $4^{\circ} \mathrm{C}$ for 15 minutes after which the supernatants were stored at $-20^{\circ} \mathrm{C}$ until assayed.

BALF was obtained by instilling three times $0.5 \mathrm{ml}$ aliquots of saline by a 22-gauge Abbocath-T catheter (Abbott, Sligo, Ireland) into the trachea. About $1.0 \mathrm{ml}$ of BALF was retrieved per mouse and cell counts were determined using a haemacytometer (Beckman Coulter, Fullerton, CA). Subsequently, differential counts were performed on citospin preparations stained with a modified Giemsa stain, Diff-Quick (Dade Behring AG, Düdingen, Switzerland). Supernatant was stored at $-80^{\circ} \mathrm{C}$ for meausrement of total protein level, thrombin-antithrombin complexes (TATC) and plasminogen activator inhibitor (PAI)-1.

\section{Lung histopathology}

For histopathology lungs were fixed in 4\% formalin and embedded in paraffin. Sections $4 \mu \mathrm{m}$ in diameter were stained with $\mathrm{H} \& \mathrm{E}$ and analysed by a pathologist who was blinded for group identity. To score lung injury we used a modified VILI histopathology scoring system as previously described [2]. VILI was scored according to the following four items: alveolar congestion; haemorrhage; infiltration or aggregation of neutrophils in airspace or vessel wall; and thickness of the alveolar wall/hyaline membrane formation. A score of 0 represented normal lungs; 1 represented mild, less than $25 \%$ lung involvement; 2 represented moderate, 25 to $50 \%$ lung involvement; 3 represented severe, 50 to $75 \%$ lung involvement; and 4 represented very severe, more than $75 \%$ lung involvement. An overall score of VILI was obtained based on the summation of all the scores from normal or ventilated lungs ( $n=12$ per group).

\section{Assays}

Total protein levels in BALF were determined using a Bradford Protein Assay Kit (OZ Biosciences, Marseille, France) according to the manufacturers' instructions with BSA as standard. Cytokine levels in blood lung homogenates were measured by ELISA according to the manufacturer's instructions. Tumour necrosis factor (TNF) $\alpha$, interleukin (IL) 6, macrophage inflammatory protein (MIP) 2 and keratinocyte-derived chemokine (KC) assays were all obtained from R\&D Systems (Abingdon, UK). TATc levels in BALF were measured with a mouse specific ELISA as previously described [16]. Levels of PAI-1 were measured by means of a commercially available ELISA (Kordia, Leiden, the Netherlands).

\section{Statistical analysis}

All data in the results are expressed as mean \pm standard deviation or median \pm interquartile range (IOR), where appropriate. To detect differences between groups the Dunnett method or Mann Whitney $U$ test, in conjunction with two-way analysis of variance was performed. Haemodynamics were measured in 12 animals, all other measurements were performed in six animals. A p value of less than 0.05 was considered significantly. All statistical analyses were carried out using SPSS 12.0.2 (SPSS, Chicago, IL).

\section{Results}

\section{Haemodynamic and ventilatory monitoring}

All animals survived five hours of MV after which they were euthanased; control animals survived anaesthesia and were 
also euthanased after five hours. The systolic blood pressure and heart rate remained stable in all animals for the entire duration of the experiment, with no differences noted between mice strains, MV strategies and fluid strategies. Although blood gas analysis from $\mathrm{LV}_{\mathrm{T}}$ mice and $\mathrm{HV}_{\mathrm{T}}$ mice using normal saline revealed metabolic acidosis after five hours of $\mathrm{MV}$ (in C57Bl/6 mice $\mathrm{pH}$ with $\mathrm{LV}_{\mathrm{T}}=7.17 \pm 0.07$ and $\mathrm{pH}$ with $\mathrm{HV}_{\mathrm{T}}=$ $7.23 \pm 0.06$, and in BALB/c mice $\mathrm{pH}$ with $\mathrm{LV}_{\mathrm{T}}=7.22 \pm 0.04$ and $\mathrm{pH}$ with $\mathrm{HV}_{\mathrm{T}}=7.11 \pm 0.07$, Tables 1 and 2) with the use of sodium bicarbonate metabolic acidosis was prevented (in C57Bl/6 mice $\mathrm{pH}$ with $\mathrm{LV}_{\mathrm{T}}=7.41 \pm 0.07$ and $\mathrm{pH}$ with $\mathrm{HV}_{\mathrm{T}}=$ $7.49 \pm 0.02$, and in BALB/c mice $\mathrm{pH}$ with $\mathrm{LV}_{\mathrm{T}}=7.42 \pm 0.05$ and $\mathrm{pH}$ with $\mathrm{HV}_{\mathrm{T}}=7.37 \pm 0.08$ ). Arterial oxygenation in $\mathrm{C} 57 \mathrm{Bl} / 6$ mice was significantly higher in $\mathrm{HV}_{\mathrm{T}}$-mice as compared with $\mathrm{LV}_{\mathrm{T}}$-mice $(205 \pm 33$ vs. $141 \pm 22 \mathrm{mmHg}, \mathrm{p}<$ $0.001)$. No differences regarding oxygenation were found between MV-groups in BALB/c mice (partial pressure of arterial oxygen $\left(\mathrm{PaO}_{2}\right)$ for $\mathrm{HV}_{\mathrm{T}}=167 \pm 50$ and $\mathrm{PaO}_{2}$ for $\mathrm{LV}_{\mathrm{T}}=181$ $\pm 42 \mathrm{mmHg}$ ).

\section{Lung histopathology scores}

The histopathological changes were minor (Figure 1 and Table 3). For both mice strains the lung histopathology score was higher in $\mathrm{HV}_{\mathrm{T}}$ mice as compared with controls. However, no differences were noted between mice strains, MV strategies and fluid strategies.

\section{Wet-to-dry ratios, BALF-protein content and neutrophil influx}

In $\mathrm{C} 57 \mathrm{BI} / 6$ mice lung wet-to-dry ratios were significantly higher with both MV strategies compared with controls $\left(\mathrm{LV}_{\mathrm{T}}\right.$ mice $=4.8 \pm 0.3$ and $\mathrm{HV}_{\mathrm{T}}$ mice $=5.3 \pm 0.5$, as compared with control mice $=4.2 \pm 0.2 ; \mathrm{p}<0.01$ ). Wet-to-dry ratios in $\mathrm{HV}_{\mathrm{T}}$ mice were also significantly higher as compared with $L V_{T}$ mice $(p=.009)$. For $B A L B / c$ mice higher lung wet to dry ratios were found in $\mathrm{HV}_{\mathrm{T}}$ mice (5.6 \pm 0.6 as compared with $4.6 \pm 0.4$ in $\operatorname{LV}_{\mathrm{T}}$ mice $(p<0.001)$ and $4.5 \pm 0.2$ in control mice $(p<$
0.001), respectively). No significant differences were found between $\mathrm{LV}_{\mathrm{T}}$ mice and control mice.

Total BALF protein levels in $\mathrm{C} 57 \mathrm{BI} / 6$ were significantly higher in $\mathrm{HV}_{\mathrm{T}}$ mice as compared with $\mathrm{LV}_{\mathrm{T}}$ mice $(\mathrm{p}=.012)$ and control mice $(p=.008$; Figure 2). No significant difference was found between $L_{T}$ mice and control mice. In BALB/c mice, total BALF protein levels were significantly higher in $\mathrm{HV}_{\mathrm{T}}$ mice as compared with $L V_{T}$ mice and control mice $(p<.001)$. No significant difference was found between $L_{T}$ mice and control mice.

The numbers of neutrophils in BALF were significantly higher in $\mathrm{HV}_{\mathrm{T}}$ mice as compared with control mice in both mice strains (Figure 1 and Table 3). Neutrophil counts in BALF from $\mathrm{HV}_{\mathrm{T}}$ mice did not differ from $\mathrm{LV}_{\mathrm{T}}$ mice.

\section{Pulmonary and plasma cytokine levels}

In the $\mathrm{HV}_{\mathrm{T}}$ group of both mice strains, higher pulmonary levels of TNF- $\alpha$ were found as compared with the $L_{\mathrm{T}}$ group $(\mathrm{p}<$ 0.05 ) and control group ( $\leq 0.001$; Figure 3$)$. In BALBc mice only, pulmonary levels of TNF- $\alpha$ in $L_{T}$ mice were higher as compared with control mice $(p=0.018)$. Pulmonary levels of IL- 6 in the $\mathrm{HV}_{\mathrm{T}}$ group of both mice strain were higher as compared with the $L_{\mathrm{T}}$ group and control group. Only for BALBc mice a significant difference between $L_{T}$ mice and control mice were found. For pulmonary levels of MIP-2 in C57BI/6 mice higher levels were found in $\mathrm{HV}_{\mathrm{T}}$ mice and $L V_{T}$ mice as compared with control $(p=0.001)$. No difference was found between $L V_{T}$ mice and $\mathrm{HV}_{\mathrm{T}}$ mice in this mice strain. In BALBc mice, higher pulmonary levels of MIP-2 in the $\mathrm{HV}_{\mathrm{T}}$ group were found as compared with the $L V_{T}$ group and control group, with also a significant difference between $\mathrm{HV}_{T}$ mice and $L V_{T}$ mice. In both mice strain higher pulmonary levels of $\mathrm{KC}$ were found in the $\mathrm{HV}_{\mathrm{T}}$ group as compared with the $\mathrm{LV}_{\mathrm{T}}$ group and control group $(p=0.001)$. Only in BALBc mice, there was also a significant difference between $L V_{T}$ mice and control mice.

Table 1

Arterial blood gas analysis in C57BI/6 mice.

\begin{tabular}{|c|c|c|c|c|c|}
\hline & \multirow[t]{2}{*}{ Control } & \multicolumn{2}{|c|}{ Low $\mathrm{V}_{\mathrm{T}}$} & \multicolumn{2}{|c|}{ High $\mathrm{V}_{\mathrm{T}}$} \\
\hline & & $\mathrm{NaCl}$ & $\mathrm{NaHCO}_{3}$ & $\mathrm{NaCl}$ & $\mathrm{NaHCO}_{3}$ \\
\hline $\mathrm{pH}$ & $7.42(0.04)$ & $7.17(0.07) \neq$ & $7.41(0.07)$ & $7.23(0.06) \neq$ & $7.49(0.02)$ \\
\hline $\mathrm{PaCO}_{2}(\mathrm{mmHg})$ & $\begin{array}{c}34.4 \\
\text { (32.2 to } 38.3)\end{array}$ & $\begin{array}{c}50.1 \\
\text { (36.7 to } 59.6)\end{array}$ & $\begin{array}{c}45.0 \\
\text { (38.6 to } 50.0)\end{array}$ & $\begin{array}{c}33.7 \\
\text { (32.1 to } 34.0)\end{array}$ & $\begin{array}{c}31.0 \\
\text { (27.6 to 34.4) }\end{array}$ \\
\hline $\mathrm{PaO}_{2}(\mathrm{mmHg})$ & & $133(15)$ & $148(28)$ & $186(45)$ & $223(20)$ \\
\hline $\mathrm{HCO}_{3}^{-}(\mathrm{mmol} / \mathrm{l})$ & $\begin{array}{c}21.4 \\
\text { (21.1 to } 24.1)\end{array}$ & $\begin{array}{c}16.6 \\
(15.2 \text { to } 18.9)\end{array}$ & $\begin{array}{c}28.0 \\
\text { (26.1 to } 30.0)\end{array}$ & $\begin{array}{c}14.6 \\
(13.3 \text { to } 15.6)\end{array}$ & $\begin{array}{c}24.9 \\
\text { (21.3 to } 25.5)\end{array}$ \\
\hline $\mathrm{BE}$ & $\begin{array}{c}-1.3 \\
(-2.3 \text { to }-0.5)\end{array}$ & $\begin{array}{c}-11.7 \\
(-12.5 \text { to }-10.2)\end{array}$ & $\begin{array}{c}4.1 \\
(1.3 \text { to } 6.0)\end{array}$ & $\begin{array}{c}-12.8 \\
(-13.4 \text { to }-10.1)\end{array}$ & $\begin{array}{c}2.3 \\
(-0.4 \text { to } 2.9)\end{array}$ \\
\hline
\end{tabular}

Data are mean (SD) or median [IQR]; Control = spontaneously breathing mice; Low $\mathrm{V}_{T}=$ mice ventilated for five hours with a $\mathrm{V}_{T}$ of $7.5 \mathrm{ml} / \mathrm{kg}$; High $V_{T}=$ mice ventilated for five hours with a $V_{T}$ of $15 \mathrm{ml} / \mathrm{kg} . \mathrm{n}=6$ per group. ${ }^{\star} \mathrm{p}<0.05 ; \neq \mathrm{p}<0.001 \mathrm{vs}$. control mice.

$\mathrm{PaCO}_{2}=$ partical pressure of arterial carbon dioxide; $\mathrm{PaO}_{2}=$ partical pressure of arterial oxygen; $\mathrm{BE}=$ base excess. 
Arterial blood gas analysis in BALB/c mice.

\begin{tabular}{|c|c|c|c|c|c|}
\hline & \multirow[t]{2}{*}{ Control } & \multicolumn{2}{|c|}{ Low $\mathbf{V}_{\mathrm{T}}$} & \multicolumn{2}{|c|}{ High $\mathrm{V}_{\mathrm{T}}$} \\
\hline & & $\mathrm{NaCl}$ & $\mathrm{NaHCO}_{3}$ & $\mathrm{NaCl}$ & $\mathrm{NaHCO}_{3}$ \\
\hline $\mathrm{PH}$ & $7.34(0.05)$ & $7.22(0.04)^{\star}$ & $7.42(0.05)$ & $7.11(0.07) \neq$ & $7.37(0.08)$ \\
\hline $\mathrm{PaCO}_{2}(\mathrm{mmHg})$ & $\begin{array}{c}39.3 \\
\text { (31.6 to } 51.3)\end{array}$ & $\begin{array}{c}35.7 \\
(31.1 \text { to } 39.5)\end{array}$ & $\begin{array}{c}41.2 \\
\text { (35.3 to } 43.6)\end{array}$ & $\begin{array}{c}40.8 \\
\text { (37.0 to } 55.6)\end{array}$ & $\begin{array}{c}44.3 \\
\text { (36.1 to } 51.7)\end{array}$ \\
\hline $\mathrm{PaO}_{2}(\mathrm{mmHg})$ & & $193(36)$ & $168(48)$ & $173(51)$ & $161(50)$ \\
\hline $\mathrm{HCO}_{3}-(\mathrm{mmol} / \mathrm{l})$ & $\begin{array}{c}21.1 \\
(17.9 \text { to } 24.1)\end{array}$ & $\begin{array}{c}14.4 \\
(12.9 \text { to } 15.2)\end{array}$ & $\begin{array}{c}25.2 \\
(23.6 \text { to } 25.9)\end{array}$ & $\begin{array}{c}13.5 \\
(12.1 \text { to } 14.7)\end{array}$ & $\begin{array}{c}24.5 \\
\text { (22.7 to } 25.4)\end{array}$ \\
\hline $\mathrm{BE}$ & $\begin{array}{c}-3.9 \\
(-6.2 \text { to }-2.5)\end{array}$ & $\begin{array}{c}-12.3 \\
(-13.6 \text { to }-11.8)\end{array}$ & $\begin{array}{c}0.15 \\
(-1.1 \text { to } 2.2)\end{array}$ & $\begin{array}{c}-15.9 \\
(-16.7 \text { to }-14.8)\end{array}$ & $\begin{array}{c}-0.7 \\
(-2.4 \text { to }-0.1)\end{array}$ \\
\hline
\end{tabular}

Data are mean (SD) or median (IQR); Control = spontaneously breathing mice; Low $\mathrm{V}_{T}=$ mice ventilated for five hours with a $\mathrm{V}_{T}$ of $7.5 \mathrm{ml} / \mathrm{kg}$; High $\mathrm{V}_{\mathrm{T}}=$ mice ventilated for five hours with a $\mathrm{V}_{\mathrm{T}}$ of $15 \mathrm{ml} / \mathrm{kg} . \mathrm{n}=6$ per group. $\neq \mathrm{p}<0.001 \mathrm{vs}$. control mice. $\mathrm{PaCO}_{2}=$ partical pressure of arterial carbon dioxide; $\mathrm{PaO}_{2}=$ partical pressure of arterial oxygen; $\mathrm{BE}=$ base excess.

Plasma levels of IL- 6 and $\mathrm{KC}$ were elevated in the both ventilation groups, with higher levels in the $\mathrm{HV}_{\mathrm{T}}$ group (Figure 4). Plasma levels of TNF- $\alpha$ and MIP-2 were below the detection limit of the assay (data not shown).

\section{Pulmonary coagulopathy}

TATc levels in BALF were significantly higher in $\mathrm{HV}_{\mathrm{T}}$ mice in both mice strain as compared with $\mathrm{LV}_{\mathrm{T}}$ mice and control $(\mathrm{p}<$ 0.001 ; Figure 5). No significant difference was found between $\mathrm{LV}_{\mathrm{T}}$ mice and control mice in both mice strain. Levels of PAl-1 were not significantly different in $\mathrm{C} 57 \mathrm{BI} / 6$ mice. BALB/c mice did show increased PAl-1 levels in the $\mathrm{HV}_{\mathrm{T}}$ group as compared with the $L V_{T}$ group and control group $(p<0.001)$. No differences were found between $\mathrm{LV}_{\mathrm{T}}$ mice and control mice.

\section{Lung injury with different fluid support strategies}

The different fluid support strategies showed no difference in endpoint of VILI, except for pulmonary MIP-2 and IL-6 levels in $\mathrm{C} 57 \mathrm{BI} / 6$ mice. MIP-2 levels were significantly higher in $\mathrm{HV}_{\mathrm{T}}$ mice and $L V_{T}$ mice that received sodium bicarbonate as compared with mice that received normal saline $(p<0.01$; Figure 3). Pulmonary IL-6 levels were significantly higher in $\mathrm{HV}_{\mathrm{T}}$ mice receiving sodium bicarbonate as compared with mice receiving normal saline $(p=0.026)$.

\section{Discussion}

We here show MV to cause VILI in healthy lungs (i.e. in the absence of a 'priming' lung insult). VILI did not only develop in animals ventilated with $\mathrm{HV}_{\mathrm{T}}$ but also in animals ventilated with $\mathrm{LV}_{\mathrm{T}}$, although to a lesser extent. We chose an MV strategy that closely reflects the human setting by using clinically relevant (i.e. physiological) $V_{T}$, preventing shock and gross lung histopathological changes. Although we hypothesised that preventing metabolic acidosis would affect the several endpoints of VILI, we showed that correction of the acid-base balance did not affect VILI.

We developed and tested a model of VILI in two commonly used mice strains using clinically relevant $\mathrm{V}_{\mathrm{T}}$ and preventing hypovolaemia with fluid support. By using a clinically relevant $\mathrm{V}_{\mathrm{T}}$ and fluid support we prevented shock. By using sodium bicarbonate instead of normal saline, metabolic acidosis was prevented. We developed a model that enhances translation of results into clinical practice and/or future studies. To our best knowledge, this is one of the first studies that compares more physiological $\mathrm{V}_{\mathrm{T}}$ then previously used in healthy lungs of mice.

Our model has several limitations. First, $\mathrm{V}_{\mathrm{T}}$ in $\mathrm{HV}_{\mathrm{T}}$ mice are still quite large (about $15 \mathrm{ml} / \mathrm{kg}$ ). Although lung-protective ventila-

Table 3

Cell counts in lung lavage fluid and histopathological examination of lung tissue of C57BI/6 mice.

\begin{tabular}{|c|c|c|c|}
\hline & Control & $\mathrm{LV}_{\mathrm{T}}$ & $\mathrm{HV}_{\mathrm{T}}$ \\
\hline Total cells $\left(\times 10^{4} / \mathrm{ml} \mathrm{BALF}\right)$ & 44 (30 to 45$)$ & 23 (14 to 221$)$ & 14 (10 to 20$)$ \\
\hline Neutrophils (× 104/ml BALF) & 0.13 (0.0 to 0.73$)$ & $1.9(1.2$ to 2.8$)$ & $4.5(3.9 \text { to } 12.7)^{\star}$ \\
\hline VILI-score & 0.0 (0.0 to 0.5$)$ & 1.0 (0.0 to 3.0$)$ & $2.0(1.0 \text { to } 4.5)^{\star}$ \\
\hline
\end{tabular}

Data are presented as median (IOR). Control $=$ spontaneously breathing mice, $\mathrm{LV}_{\mathrm{T}}=$ low tidal volumes, $\mathrm{HV}$ broncho-alveolar lavage fluid, VILI = ventilator-induced lung injury. $n=6$ per group. ${ }^{\star} p<0.05$ vs. control. 
Figure 1
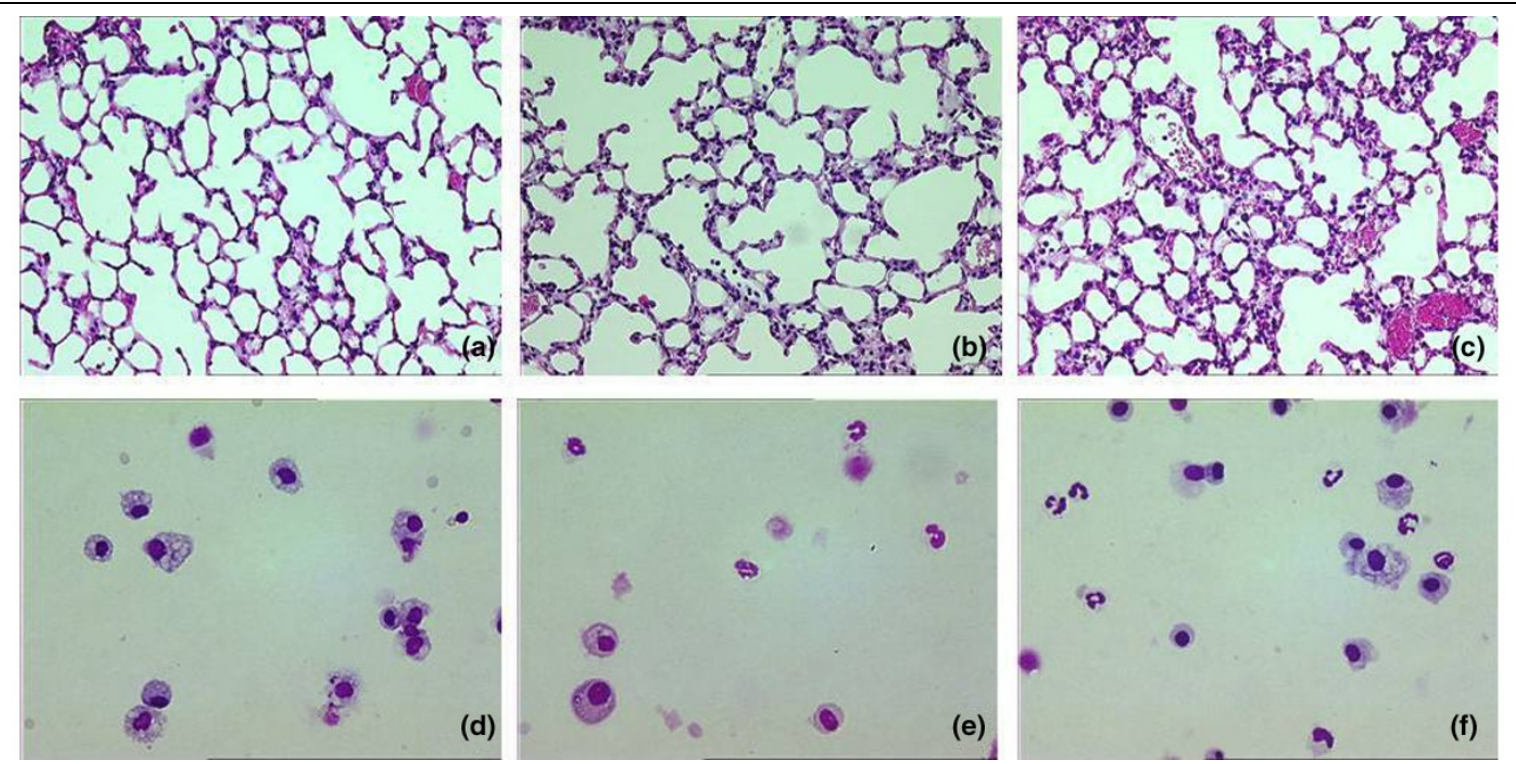

Histological specimens from the lungs of spontaneously breathing mice and mice ventilated with low/high tidal volumes. (a to $\mathrm{c}$ ) Images of histological specimens from the lungs of spontaneously breathing C57BI/6 mice (control) or ventilated with low tidal volumes $\left(\mathrm{LV}_{T}\right)$ and high $\mathrm{V}_{T}$ $\left(H V_{T}\right)$ for five hours. H\&E stain; magnification 200x. (a) Control mice; (b) $L V_{T}$ mice; (c) $H V_{T}$ mice. (d to e) Images of citospin preparations of $B A L F$ of C57BI/6 mice stained with Diff-Quick. (d) control mice; (e) $\mathrm{LV}_{\mathrm{T}}$ mice; (f) $\mathrm{HV}_{\mathrm{T}}$ mice.

tion with the use of $L V_{T}$ is underused in patients with acute lung injury (ALI)/adult respiratory distress syndrome (ARDS) [17] and patients at risk for ALI/ARDS [18], in the clinical arena $V_{T}$ have declined gradually over the past 10 years $[19,20]$. However, $\mathrm{V}_{\mathrm{T}}$ of as large as $15 \mathrm{ml} / \mathrm{kg}$ are still reported to be used $[21,22]$. Therefore our comparison may still reveal relevant information on lung injury caused by MV.
Second, $\mathrm{LV}_{\mathrm{T}}$ ventilation can promote development of atelectasis. This may, in part, explain the lower oxygenation levels with use of $L_{T}$ in our experiments. It was recently demonstrated that periodic recruitment with relatively frequent deep inflations during ventilation with $L V_{T}$ can improve oxygenation, ventilation and lung mechanical function with no evidence of lung injury by two hours in mechanically ventilated mice [23]. Therefore, lung injury seen in our $L_{\mathrm{T}}$ mice could be caused by atelectotrauma.

Figure 2
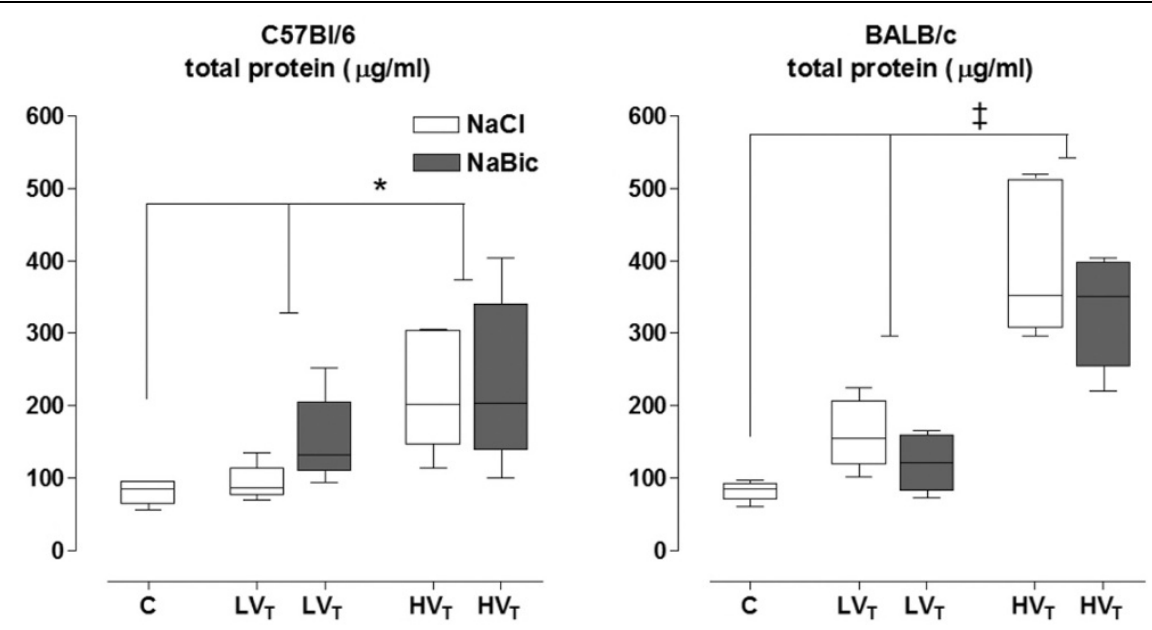

Total protein level in control mice and mice ventilated with low/high tidal volumes. Total protein level in control mice, and in mice ventilated with low tidal volumes $\left(\mathrm{LV}_{\mathrm{T}}\right)$ and high $\mathrm{V}_{\mathrm{T}}\left(\mathrm{HV}_{\mathrm{T}}\right)$ for five hours. Two fluid strategies (normal saline (white boxes) and sodium bicarbonate (grey boxes)) were compared. Data represent median and interquartile range of six mice. ${ }^{*} \mathrm{p}<0.05\left(\mathrm{HV}_{\mathrm{T}} v s . \mathrm{LV}_{\mathrm{T}}\right) ; \neq \mathrm{p}<0.001\left(\mathrm{HV}_{\mathrm{T}} v s . \mathrm{LV}_{\mathrm{T}}\right)$. 
Figure 3
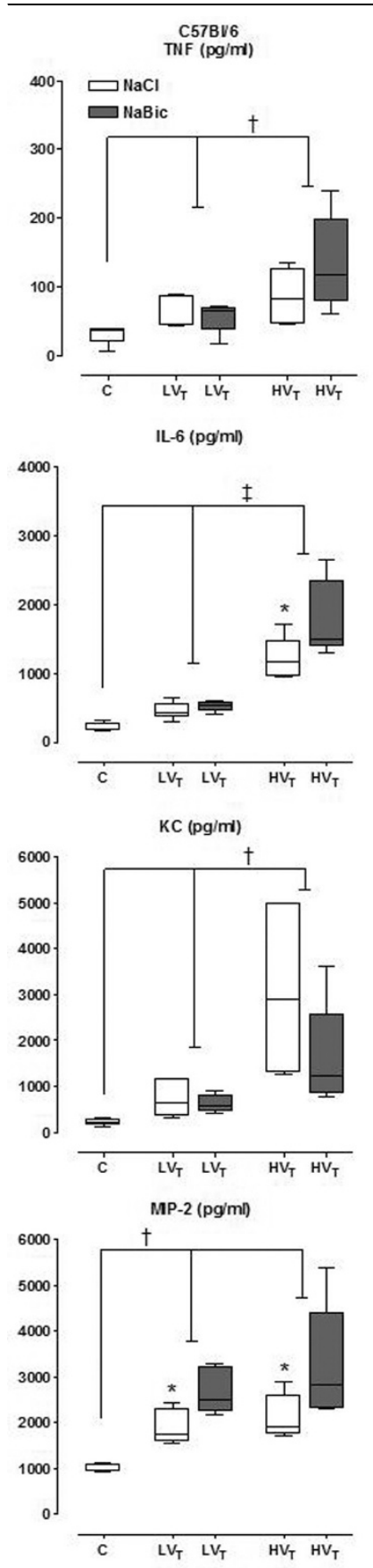
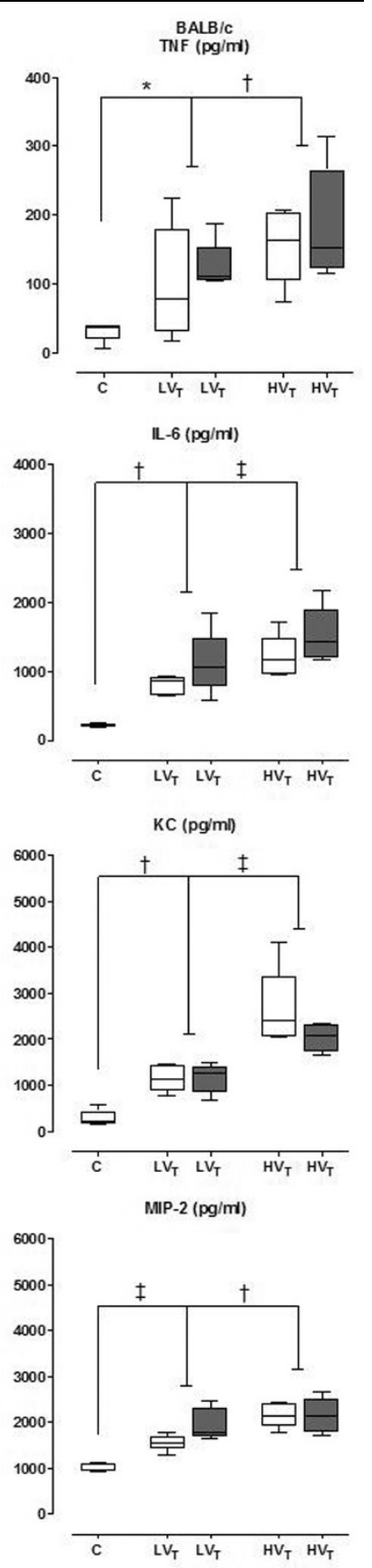

Pulmonary levels of tumour necrosis factor (TNF)- $\alpha$, interleukin (IL)-6, keratincyte-derived cytokine (KC) and macrophage inflammatory protein (MIP)-2 in lung tissue homogenate. Pulmonary levels of TNF- $\alpha, \mathrm{IL}-6, \mathrm{KC}$ and MIP-2 and in lung tissue homogenate in control mice, and in mice ventilated with low tidal volumes $\left(\mathrm{LV}_{\mathrm{T}}\right)$ and high $\mathrm{V}_{\mathrm{T}}$ $\left(H V_{T}\right)$ for five hours. Two fluid strategies (normal saline (white boxes) and sodium bicarbonate (grey boxes)) were compared. Data represent median and interquartile range of six mice. ${ }^{*} \mathrm{p}<0.05\left(\mathrm{LV}_{\mathrm{T}} v s\right.$. control or sodium bicarbonate vs. saline, IL- 6 and MIP-2 in C57BI/ 6 mice); $t p<$ $0.01\left(\mathrm{HV}_{\mathrm{T}}\right.$ vs. $\mathrm{LV}_{\mathrm{T}}$ or $\mathrm{LV}_{\mathrm{T}}$ vs. control); $\neq \mathrm{p}<0.001\left(\mathrm{HV}_{\mathrm{T}}\right.$ vs. $\mathrm{LV}_{\mathrm{T}}$ or $\mathrm{LV}_{\mathrm{T}}$ vs. control).

Third, our non-ventilated control animals were not sham operated, did not receive fluid resuscitation and were breathing room air as opposed to our ventilated animals. It can be suggested that the invasive surgical procedure has an influence on the inflammatory reaction by entering endotoxins and/or bacteria into the circulation. MV in combination with prolonged exposure to hyperoxia ( $>95 \%$ of oxygen) augmented lung injury [24]. However, lung injury caused by $50 \%$ of oxygen, as used in our ventilated mice, has not been previously reported.

Fourth, in accordance with previous models of murine ventilation, we did not use moisture breathing gas. The problem is that drops will obstruct the inspiratory tubing. We do realise that this is a limitation of our and previous models of murine ventilation.

VILI was clearly present with the use of $\mathrm{HV}_{\mathrm{T}}$ after five hours of MV. For most of our endpoints of VILI significant differences were found between $\mathrm{HV}_{\mathrm{T}}$ mice and $\mathrm{LV}_{\mathrm{T}}$ mice. Of more interest, with $L V_{T}$ VILI also developed. This finding is in accordance with a previous report, where low $V_{T}(8 \mathrm{ml} / \mathrm{kg})$ for four hours in mice resulted in a reversible inflammatory reaction, while preserving tissue integrity [25]. On the other hand, Altemeier and colleagues demonstrated that MV with tidal volumes of $10 \mathrm{ml} / \mathrm{kg}$ for six hours did not cause significant cytokine expression [26]. In the study of Altemeier and colleagues, cytokines were measured in the BALF, while in our study and in the study of Vaneker and colleagues cytokines were measured in lung homogenate. Maybe cytokines were still in the sub-epithelium and did not migrate further into the alveoli. Thus, even the use of $L V_{T}$ could be considered to be potentially harmful, at least in a murine setting. In disagreement with some reports that did not show any effect of larger $V_{\top}$ in patients with non-injured lungs [21,22], several articles did display harmful effects of large $\mathrm{V}_{\mathrm{T}}$. In one study on postoperative MV after cardiopulmonary bypass surgery, MV with tidal volumes of $6 \mathrm{ml} / \mathrm{kg}$ predicted bodyweight (PBW) resulted in significantly lower BALF TNF- $\alpha$ levels as compared with tidal volumes of $12 \mathrm{ml} / \mathrm{kg}$ PBW [27]. These results were confirmed by others, who showed that the use of large tidal volumes of 10 to $12 \mathrm{ml} / \mathrm{kg}$ resulted in an increase of bronchoalveolar lavage fluid and plasma IL-6 and IL-8 levels as compared with lower $\mathrm{V}_{\mathrm{T}}$ of $8 \mathrm{ml} /$ $\mathrm{kg}$ [28]. In our study, patients ventilated with $\mathrm{HV}_{\mathrm{T}}(12 \mathrm{ml} / \mathrm{kg}$ PBW) for five hours showed upregulation of pulmonary inflammatory mediators as opposed to patients ventilated with $L V_{T}$ $(6 \mathrm{ml} / \mathrm{kg})$ [29]. Unrecognised differences in MV between mice and the human setting may be responsible for this difference.

With $\mathrm{V}_{\mathrm{T}}$ as used in our experiments histopathological changes were minor. In previously published studies the VILI score was about 2 in the low $V_{T}$ or low pressure group and about 7 in the high $\mathrm{V}_{\mathrm{T}}$ or high pressure group [2,30]. Worth mentioning is that $\mathrm{V}_{\mathrm{T}}$ or pressures used in the high $\mathrm{V}_{\mathrm{T}}$ group in these former studies were about twice as high as in our study protocol. In a previously mentioned study in which C57BI/6 mice were ven- 


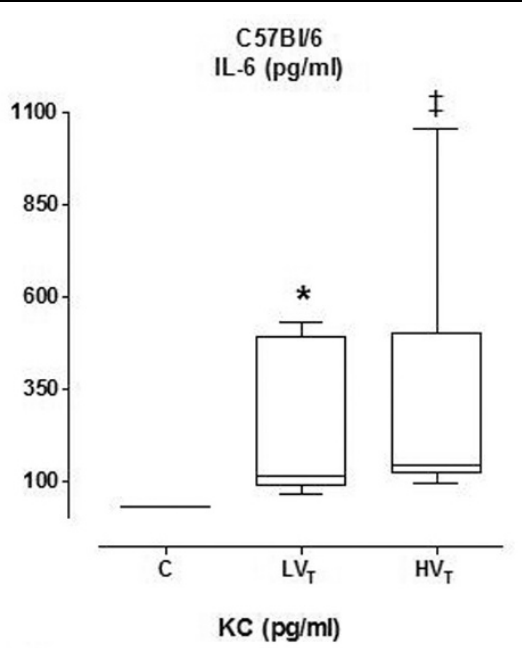

$\mathrm{BALB} / \mathrm{c}$

$\mathrm{IL}-6(\mathrm{pg} / \mathrm{ml})$
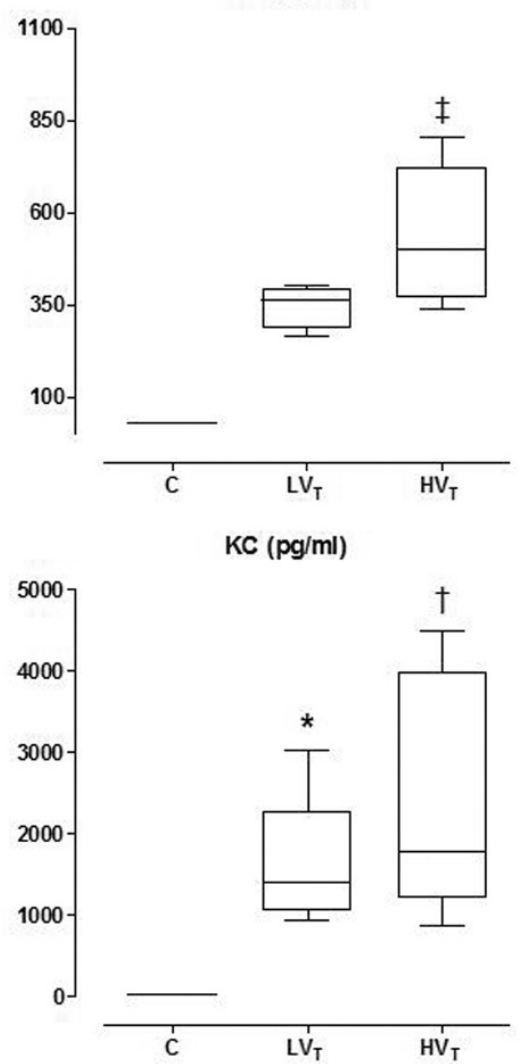

Plasma levels of interleukin (IL)- 6 and keratinocyte-derived chemokine (KC). Plasma levels of IL-6 and KC in control mice, and in mice ventilated with low tidal volumes $\left(\mathrm{LV}_{\mathrm{T}}\right)$ and high $\mathrm{V}_{\mathrm{T}}\left(\mathrm{HV}_{\mathrm{T}}\right)$ for five hours. Data of the two fluid strategies are pooled. Data represent median and interquartile range of six mice. Levels of IL- 6 and $\mathrm{KC}$ in control mice were below the detection limit of the assay. ${ }^{*} p<0.05$ vs. control; $\uparrow p<0.01 v s$. LV $V_{T} ; \neq p$ $<0.001$ vs. $\mathrm{LV}_{\mathrm{T}}$.

tilated for four hours with $\mathrm{V}_{\mathrm{T}}$ of $8 \mathrm{ml} / \mathrm{kg}$, electron microscopy revealed intact epithelial cell and basement membranes with sporadically minimal signs of partial endothelial detachment [25].

Although it is well known that acid-base parameters are reliable indicators of the general condition of the animal, these parameters are not or only partly assessed in previous murine models of MV $[2,9,26,31]$. Acid-base balance in spontaneously breathing mice are mainly under isoflurane anaesthesia [12] and reported values on $\mathrm{pH}$ are rather acidotic [32]. It has been suggested that mice have a considerably lower alveolar and arterial $\mathrm{PCO}_{2}$ than other mammals $\left(\mathrm{PaCO}_{2}\right.$ ranging from 33 to $41 \mathrm{mmHg}$ ). However, instrumentation of animals cannot be completely excluded as causative [33]. Here we show normal values for $\mathrm{pH}$ and $\mathrm{PaCO}_{2}$ in $\mathrm{C57BL} / 6$ mice and BALB/c mice after brief anaesthesia. Our animals developed metabolic acidosis when normal saline was used. Metabolic acidosis in mice can be induced by isoflurane anaesthesia and/or saline administration [12,13]. However we can not totally exclude that metabolic acidosis was not caused by some haemodynamic impairment, although blood pressure measured during five hours of MV was stable. Probably the effects of anaesthetics during five hour of MV are more impressive in terms of fluid losses. For this reason we choose a fluid resuscitation regimen of $0.2 \mathrm{ml}$ for 30 minutes intraperitoneally. In the present study we only found subtle differences in endpoints of VILI between the two fluid therapies. Nevertheless, we favour the use of sodium bicarbonate instead of normal saline as fluid support therapy to prevent metabolic acidosis, because severe acidosis may influence unmeasured endpoints of VILI.

We found higher plasma levels of KC and IL-6 as compared with control mice and levels were higher in $\mathrm{HV}_{\mathrm{T}}$ mice. This finding is in accordance with data from human studies. Indeed, in patients with ALI/ARDS a lung protective MV strategy using $\mathrm{LV}_{\mathrm{T}}$ and sufficient PEEP levels resulted in significantly lower systemic inflammatory mediators as compared with ALI/ARDS patients ventilated with a more conventional MV strategy, using $\mathrm{HV}_{\mathrm{T}}$ [34]. 

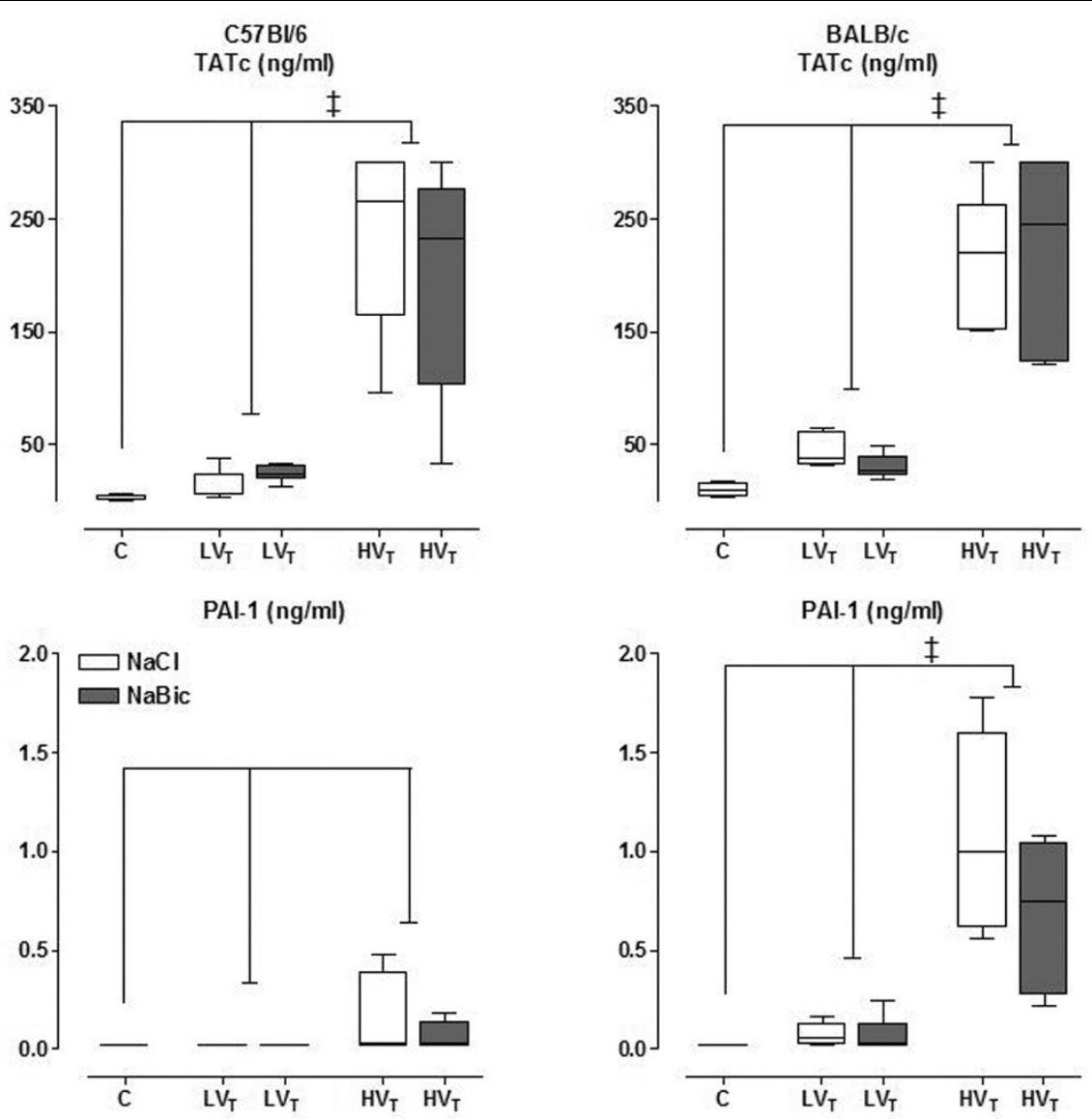

Thrombin-antithrombin complexes (TATC) levels and plasminogen activator inhibitor (PAI)-1 levels in bronchoalveolar lavage fluid. TATc levels and PAl-1 levels in bronchoalveolar lavage fluid in control mice, and in mice ventilated with low tidal volumes $\left(\mathrm{LV}_{T}\right)$ and high $\mathrm{V}_{\mathrm{T}}\left(\mathrm{HV}_{\mathrm{T}}\right)$ for five hours. Two fluid strategies (normal saline (white boxes) and sodium bicarbonate (grey boxes)) were compared. Data represent median and interquartile range of six mice. $\neq \mathrm{p}<0.001\left(\mathrm{HV}_{\mathrm{T}} v s . \mathrm{LV}_{\mathrm{T}}\right)$.

We chose an one-hit model instead of a two-hit model to avoid the interference of an additional source of inflammation. Whether MV per se initiates pulmonary inflammation in patients with non-injured lungs is still unclear, although we have shown that a lung protective MV strategy $\left(\mathrm{V}_{\mathrm{T}}\right.$ of $6 \mathrm{ml} / \mathrm{kg}$ PBW and $10 \mathrm{cmH}_{2} \mathrm{O}$ PEEP) attenuates pulmonary coagulation caused by a more conventional MV strategy $\left(\mathrm{V}_{\mathrm{T}}\right.$ of $12 \mathrm{ml} /$ $\mathrm{kg}$ and no PEEP) [35]. In addition, $M V$ with lower $\mathrm{V}_{\mathrm{T}}$ and PEEP attenuated the increase of pulmonary levels of IL-8, myeloperoxidase and elastase as seen with higher $\mathrm{V}_{\mathrm{T}}$ and no PEEP [29]. The inflammatory changes observed in healthy lungs are merely physiological adaptations to the artificial process of MV. Our model offers opportunities to study the pathophysiological mechanisms behind VILI and the contribution of MV to the 'multiple-hit' concept.

Several studies suggest pulmonary coagulopathy is also a feature of VILI. Indeed, we have shown that MV using high $\mathrm{V}_{\mathrm{T}}$ resulted in increased alveolar thrombin generation [35]. It is likely that the alveolar epithelium can initiate intra-alveolar coagulation by expressing active tissue factor [36]. Recently, we also showed $\mathrm{MV}$ with high $\mathrm{V}_{\mathrm{T}}$ to attenuate fibrinolysis in rats, in part via upregulation of PAl-1 [7,37]. These results are in line with results from the present study. Of note, use of $L_{T}$ also resulted in profound procoagulant changes, underlining the fact that even a lung protective MV strategy to induce VILI in healthy mice.

\section{Conclusions}

In this model of VILI in two commonly used mice strains we show physiological $\mathrm{V}_{\mathrm{T}}$ to induce $\mathrm{VILI}$ in healthy mice. Lung injury was found with both $V_{T}$ used in our experiments (i.e. also with LV $_{T}$ VILI developed). This model offers opportunities to study the pathophysiological mechanisms behind VILI and the contribution of MV to lung injury in the absence of pre-existing lung injury.

\section{Competing interests}

The authors declare that they have no competing interests. 


Key messages
- MV induces VILI in mice, in the absence of a priming
pulmonary insult, with use of relevant ventilator settings.
- By using sodium bicarbonate instead of normal saline
metabolic acidosis was prevented.
- Endpoints of VILI were not influenced by metabolic
acidosis.

\section{Authors' contributions}

EW performed the experimental work, interpreted the results and drafted the manuscript. AV and GC performed the experimental work and were responsible for critical review of the manuscript. JR performed part of the experimental work. NJ participated in drafting and reviewing the manuscript. MS participated in study design, interpretation of the results and drafting the manuscript. All authors read and approved the final manuscript.

\section{Acknowledgements}

MJS is supported by an unrestricted grant of the Netherlands Organization for Health Research and Development (ZonMW); NWO-VENI grant 2004 [project number 016.056.001].

\section{References}

1. Dellinger RP, Carlet JM, Masur $\mathrm{H}$, Gerlach $\mathrm{H}$, Calandra $\mathrm{T}$, Cohen J, Gea-Banacloche J, Keh D, Marshall JC, Parker MM, Ramsay G, Zimmerman JL, Vincent JL, Levy MM: Surviving Sepsis Campaign guidelines for management of severe sepsis and septic shock. Crit Care Med 2004, 32:858-873.

2. Belperio JA, Keane MP Burdick MD, Londhe V, Xue YY, LiK, Phillips RJ, Strieter RM: Critical role for CXCR2 and CXCR2 ligands during the pathogenesis of ventilator-induced lung injury. $J$ Clin Invest 2002, 110:1703-1716.

3. Copland IB, Martinez F, Kavanagh BP, Engelberts D, McKerlie C, Belik J, Post M: High tidal volume ventilation causes different inflammatory responses in newborn versus adult lung. $A m \mathrm{~J}$ Respir Crit Care Med 2004, 169:739-748.

4. Haitsma JJ, Uhlig S, Verbrugge SJ, Goggel R, Poelma DL, Lachmann $B:$ Injurious ventilation strategies cause systemic release of IL-6 and MIP-2 in rats in vivo. Clin Physiol Funct Imaging 2003, 23:349-353.

5. Wilson MR, Choudhury S, Goddard ME, O'Dea KP, Nicholson AG, Takata M: High tidal volume upregulates intrapulmonary cytokines in an in vivo mouse model of ventilator-induced lung injury. J Appl Physio/ 2003, 95:1385-1393.

6. Wilson MR, Choudhury S, Takata M: Pulmonary inflammation induced by high-stretch ventilation is mediated by tumor necrosis factor signaling in mice. Am J Physiol Lung Cell Mol Physiol 2005, 288:L599-L607.

7. Dahlem P, Bos AP, Haitsma JJ, Schultz MJ, Wolthuis EK, Meijers JC, Lachmann B: Mechanical ventilation affects alveolar fibrinolysis in LPS-induced lung injury. Eur Respir J 2006, 28:992-998.

8. Dhanireddy S, Altemeier WA, Matute-Bello G, O'Mahony DS, Glenny RW, Martin TR, Liles WC: Mechanical ventilation induces inflammation, lung injury, and extra-pulmonary organ dysfunction in experimental pneumonia. Lab Invest 2006, 86:790-799.

9. Gurkan OU, O'Donnell C, Brower R, Ruckdeschel E, Becker PM: Differential effects of mechanical ventilatory strategy on lung injury and systemic organ inflammation in mice. Am J Physiol Lung Cell Mol Physiol 2003, 285:L710-718.

10. Imai Y Parodo J, Kajikawa O de Perrot M, Fischer S, Edwards V, Cutz E, Liu M, Keshavjee S, Martin TR, Marshall JC, Ranieri VM, Slutsky AS: Injurious mechanical ventilation and end-organ epithelial cell apoptosis and organ dysfunction in an experi- mental model of acute respiratory distress syndrome. JAMA. 2003, 289:2104-2112.

11. Haitsma JJ, Uhlig S, Goggel R, Verbrugge SJ, Lachmann U, Lachmann B: Ventilator-induced lung injury leads to loss of alveolar and systemic compartmentalization of tumor necrosis factoralpha. Intensive Care Med 2000, 26:1515-1522.

12. Sjoblom M, Nylander O: Isoflurane-induced acidosis depresses basal and PGE(2)-stimulated duodenal bicarbonate secretion in mice. Am J Physiol Gastrointest Liver Physiol 2007, 292:G899-G904.

13. Zuurbier CJ, Emons VM, Ince C: Hemodynamics of anesthetized ventilated mouse models: aspects of anesthetics, fluid support, and strain. Am J Physiol Heart Circ Physiol 2002, 282: $\mathrm{H} 2099-\mathrm{H} 2105$.

14. De Smet HR, Bersten AD, Barr HA, Doyle IR: Hypercapnic acidosis modulates inflammation, lung mechanics, and edema in the isolated perfused lung. J Crit Care 2007, 22:305-313.

15. Sinclair SE, Kregenow DA, Lamm WJ, Starr IR, Chi EY, Hlastala MP: Hypercapnic acidosis is protective in an in vivo model of ventilator-induced lung injury. Am J Respir Crit Care Med 2002, 166:403-408.

16. Sommeijer DW, van Oerle R, Reitsma PH, Timmerman JJ, Meijers JC, Spronk HM, ten Cate H: Analysis of blood coagulation in mice: pre-analytical conditions and evaluation of a homemade assay for thrombin-antithrombin complexes. Thromb $J$ 2005, 3:12.

17. Kalhan R, Mikkelsen M, Dedhiya $P$, Christie J, Gaughan $C$, Lanken PN, Finkel B, Gallop R, Fuchs BD: Underuse of lung protective ventilation: analysis of potential factors to explain physician behavior. Crit Care Med 2006, 34:300-306.

18. Gillis RC, Weireter LJ Jr, Britt RC, Cole FJ Jr, Collins JN, Britt LD: Lung protective ventilation strategies: have we applied them in trauma patients at risk for acute lung injury and acute respiratory distress syndrome? Am Surg 2007, 73:347-350.

19. Weinert CR, Gross CR, Marinelli WA: Impact of randomized trial results on acute lung injury ventilator therapy in teaching hospitals. Am J Respir Crit Care Med 2003, 167:1304-1309.

20. Young MP, Manning HL, Wilson DL, Mette SA, Riker RR, Leiter JC, Liu SK, Bates JT, Parsons PE: Ventilation of patients with acute lung injury and acute respiratory distress syndrome: has new evidence changed clinical practice? Crit Care Med 2004, 32:1260-1265.

21. Wrigge $H$, Zinserling J, Stuber $F$, von Spiegel T, Hering $R$, Wetegrove S, Hoeft A, Putensen C: Effects of mechanical ventilation on release of cytokines into systemic circulation in patients with normal pulmonary function. Anesthesiology 2000, 93:1413-1417.

22. Wrigge $H$, Uhlig $U$, Zinserling J, Behrends-Callsen $E$, Ottersbach G, Fischer M, Uhlig S, Putensen C: The effects of different ventilatory settings on pulmonary and systemic inflammatory responses during major surgery. Anesth Analg 2004, 98:775-781.

23. Allen GB, Suratt BT, Rinaldi L, Petty JM, Bates JH: Choosing the frequency of deep inflation in mice: balancing recruitment against ventilator-induced lung injury. Am J Physiol Lung Cell Mol Physiol 2006, 291:L710-L717.

24. Li LF, Liao SK, Ko YS, Lee CH, Quinn DA: Hyperoxia increases ventilator-induced lung injury via mitogen-activated protein kinases: a prospective, controlled animal experiment. Crit Care 2007, 11:R25.

25. Vaneker M, Halbertsma FJ, van Egmond J, Netea MG, Dijkman HB, Snijdelaar DG, Joosten LA, Hoeven JG van der, Scheffer GJ: Mechanical ventilation in healthy mice induces reversible pulmonary and systemic cytokine elevation with preserved alveolar integrity: an in vivo model using clinical relevant ventilation settings. Anesthesiology 2007, 107:419-426.

26. Altemeier WA, Matute-Bello G, Gharib SA, Glenny RW, Martin TR, Liles WC: Modulation of lipopolysaccharide-induced gene transcription and promotion of lung injury by mechanical ventilation. J Immunol 2005, 175:3369-3376.

27. Wrigge $\mathrm{H}$, Uhlig $\mathrm{U}$, Baumgarten $\mathrm{G}$, Menzenbach J, Zinserling J, Ernst M, Dromann D, Welz A, Uhlig S, Putensen C: Mechanical ventilation strategies and inflammatory responses to cardiac surgery: a prospective randomized clinical trial. Intensive Care Med 2005, 31:1379-1387.

28. Zupancich E, Paparella D, Turani F, Munch C, Rossi A, Massaccesi $S$, Ranieri VM: Mechanical ventilation affects inflammatory 
mediators in patients undergoing cardiopulmonary bypass for cardiac surgery: a randomized clinical trial. J Thorac Cardiovasc Surg 2005, 130:378-383.

29. Wolthuis EK, Choi G, Dessing MC, Bresser P, Lutter R, Dzoljic M, van der PT, Vroom MB, Hollmann M, Schultz MJ: Mechanical ventilation with lower tidal volumes and positive end-expiratory pressure prevents pulmonary inflammation in patients without preexisting lung injury. Anesthesiology 2008, 108:46-54.

30. Imanaka H, Shimaoka M, Matsuura N, Nishimura M, Ohta N, Kiyono $\mathrm{H}$ : Ventilator-induced lung injury is associated with neutrophil infiltration, macrophage activation, and TGF-beta 1 mRNA upregulation in rat lungs. Anesth Analg 2001, 92:428-436.

31. Li LF, Yu L, Quinn DA: Ventilation-induced neutrophil infiltration depends on c-Jun N-terminal kinase. Am J Respir Crit Care Med 2004, 169:518-524.

32. Szczesny G, Veihelmann A, Massberg S, Nolte D, Messmer K: Long-term anaesthesia using inhalatory isoflurane in different strains of mice-the haemodynamic effects. Lab Anim 2004, 38:64-69.

33. Schwarte LA, Zuurbier CJ, Ince C: Mechanical ventilation of mice. Basic Res Cardiol 2000, 95:510-520.

34. Ranieri VM, Suter PM, Tortorella C, De Tullio R, Dayer JM, Brienza A, Bruno F, Slutsky AS: Effect of mechanical ventilation on inflammatory mediators in patients with acute respiratory distress syndrome: a randomized controlled trial. JAMA. 1999, 282:54-61.

35. Choi G, Wolthuis EK, Bresser P, Levi M, van der PT, Dzoljic M, Vroom MB, Schultz MJ: Mechanical ventilation with lower tidal volumes and positive end-expiratory pressure prevents alveolar coagulation in patients without lung injury. Anesthesiology 2006, 105:689-695

36. Bastarache JA, Wang L, Geiser T, Wang Z, Albertine KH, Matthay MA, Ware LB: The alveolar epithelium can initiate the extrinsic coagulation cascade through expression of tissue factor. Tho$\operatorname{rax} 2007,62: 608-616$.

37. Dahlem P, Bos AP, Haitsma JJ, Schultz MJ, Meijers JC, Lachmann B: Alveolar fibrinolytic capacity suppressed by injurious mechanical ventilation. Intensive Care Med 2005, 31:724-732. 